\title{
Pengaruh Lingkungan Kerja Terhadap Kinerja Pegawai Pada Dinas Kependudukan Dan Pencatatan Sipil Kabupaten Barito Selatan Tahun 2021
}

\author{
The Effect of hhe Work Environment on Employee Performance in the Department \\ of Population and Civil Registration in South Barito District, 2021
}

\section{Harlina Kurniaty}

STIE Dahani Dahanai, Buntok, Central Kalimantan, Indonesia

\section{Kata Kunci: \\ Kinerja \\ Disiplik Kerja \\ Pegawai}

Keywords:

Work discipline

Performance

Employee

\section{Accepted}

Januari 2021

Published

April 2021

\begin{abstract}
Abstrak
Disiplin kerja merupakan aspek penting dalam membangkitkan kinerja pegawai yakni akan menciptakan suatu iklim kerja yang kondusif sehingga dapat bersinergi dengan meningkatkan semangat atau kegairahan kerja pegawai untuk mencapai suatu tujuan. Penelitian ini bertujuan untuk mengetahui pengaruh disiplin kerja Terhadap kinerja pegawai pada Dinas tenaga kerja dan transmigrasi Kabupaten Barito Selatan Tahun 202I .
\end{abstract}

Pada Penelitian ini, penulis menggunakan penelitian kuantitatif deskriptif. Data yang digunakan adalah data primer dan sekunder yang dikumpulkan melalui, observasi, wawancara, dokumentasi dan kuesioner. Sampel yang dijadikan obyek penelitian sebanyak 30 orang. Penelitian ini mempunyai dua varibel yaitu independen $(X)$ Disiplin Kerja dan variabel dependen $(Y)$ Kinerja Pegawai bagian pelatihan kerja dan penempatan tenaga kerja.

Hasil yang diperoleh dalam perhitungan regresi linier sederhana adalah $\mathrm{Y}=$ 18,628+0,553 x dimana nilai (a) sebesar 18,628; dan nilai koefisien (b) adalah 0,553 . Kemudian diperoleh hasil thitung $>$ dari pengujian diatas bahwa thitung $>$ ttabel $(3,374 \geq \mathrm{t}$ tabel $2,05 \mathrm{I})$ maka Ho ditolak dan Ha diterima, artinya bahwa ada pengaruh Disiplin Kerja Terhadap Kinerja Pegawai Pada Dinas Tenaga Kerja dan Transmigrasi Kabupaten Barito Selatan Tahun 2021.

Berdasarkan Kesimpulan maka dapat diketahui bahwa Pengaruh Disiplin kerja terhadap Kinerja Pegawai Bagian Pelatihan Kerja dan penempatan tenaga kerja pada Dinas tenaga kerja dan Transmigrasi Kabupaten Barito Selatan Tahun 202I Penting dikarenakan dapat meningkatkan kinerja pegawai dalam melaksanakan tugas mereka masing -masing sesuai dengan job des.

\section{Abstract}

Work discipline is an important aspect in generating employee performance which will create a conducive work climate so that it can synergize with increasing employee morale or enthusiasm to achieve a goal. This study aims to see the effect of work influence on employee performance at the Manpower and Transmigration Office of South Barito Regency in 2021.

In this study, the author of quantitative quantitative research. The data used are primary and secondary data collected through, observation, interviews, documentation and questionnaires. The sample used as the object of research was 30 people. This study has two variables, namely the independent (X) Work Discipline and the dependent variable (Y) Employee Performance in the job training and workforce placement sections.

The results obtained in the calculation of simple linear regression are $Y=18,628+$ $0.553 x$ where the value (a) is 18,628; and the coefficient value (b) is 0.553 . Then the results of tcount $>$ are obtained from the test that tcount $>$ ttable $(3.374 \geq t$ table $2.05 \mathrm{I})$ then $\mathrm{Ho}$ is rejected and $\mathrm{Ha}$ is accepted, meaning that there is an effect of work discipline on employee performance at the Manpower and Transmigration Office of South Barito Regency in 2021.

Based on the conclusion, it can be seen that the effect of work discipline on employee performance in the job training section and placement of workers at the Manpower and Transmigration Office of South Barito Regency in 202I is important because it can improve employee performance in carrying out their duties according to des jobs. 


\section{PENDAHULUAN}

Kependudukan merupakan basis utama dan fokus dari segala persoalan pembangunan. Hampir semua kegiatan pembangunan baik yang bersifat sektoral maupun lintas sektor terarah dan terkait dengan penduduk, atau dengan kata lain penduduk harus menjadi subyek sekaligus objek pembangunan. Kualitas penduduk yang baik akan melahirkan sumber daya manusia yang baik pula. Jumlah penduduk yang besar tetap akan berarti bila sebagian besar dari mereka mampu berkarya dan berpartisipasi dalam pembangunan. Sebaliknya jumlah penduduk yang besar akan menambah beban ekonomi dan pembangunan, bila tidak dapat diberdayakan. Oleh karena itu dalam mengurus semua hal yang berhubungan dengan kependudukan ditangani oleh suatu dinas dimana dinas tersebut memberikan semua bentuk pelayanan mengenai kependudukan itu sendiri, dinas tersebut yaitu Dinas Kependudukan dan Catatan Sipil. Dinas Kependudukan dan Catatan Sipil merupakan salah satu instansi pemerintah yang bertugas melayani masyarakat dalam hal pencatatan kelahiran, kematian, perkawinan, perceraian, pengesahan anak dan pengakuan anak.

Dinas Kependudukan dan Pencatatan Sipil (DISDUKCAPIL) untuk wilayah Kabupaten Barito Selatan, Kalimantan Tengah merupakan instansi pemerintah yang bertugas dalam pembantuan di bidang kependudukan dan pencatatan sipil dan tugas lainnya yang diberikan sesuai dengan lingkup tugas dan fungsinya di wilayah Barito Selatan.

Beberapa kegiatan pengelolaan SDM misalnya pengadaan, penilaian, perlindungan, memotivasi pegawai, memberdayakan pegawai, peningkatan disiplin, bimbingan, dII. Pengelolaan dan pengoptimalan sumber daya manusia tidak lepas dari faktor pegawai. Organisasi harus mempunyai pegawai yang mempunyai kinerja baik. Dengan kata lain kelangsungan suatu organisasi ditentukan oleh kinerja pegawainya.

Menurut Siagan (2002), kinerja pegawai dipengaruhi oleh beberapa faktor yaitu: gaji, lingkungan kerja, budaya organisasi, kepemimpinan dan motivasi kerja, disiplin kerja, kepuasan kerja, komunikasi dan faktor-faktor lainnya.

Dari faktor diatas, untuk meningkatkan kinerja pegawai salah satunya adalah dengan memperhatikan faktor lingkungan kerja. Organisasi selaku induk kerja harus menyediakan lingkungan kerja yang nyaman dan kondusif yang mampu memancing para pegawai untuk bekerja dengan produktif. Penyediaan lingkungan kerja secara nyaman akan mampu memberikan kepuasan kepada pegawai terhadap pekerjaan yang dilakukan dan memberikan kesan yang mendalam bagi pegawai yang pada akhirnya pegawai akan mempunyai kinerja yang baik.

Lingkungan kerja menurut Sedarmayati (200I:2I) merupakan keseluruhan alat perkakas dan bahan yang dihadapi, lingkungan sekitarnya dimana seseorang bekerja, metode kerjanya, serta pengaturan kerjanya baik sebagai perseorangan maupun sebagai kelompok.

Kondisi lingkungan kerja yang tidak sehat dapat menyebabkan para pegawai mudah stres, tidak semangat untuk bekerja, datang terlambat, demikian juga sebaliknya apabila lingkungan kerja itu sehat maka para pegawai tentunya akan semangat dalam bekerja, tidak mudah sakit, mudah untuk konsentrasi sehingga pekerjaan menjadi cepat selesai sesuai dengan target. Lingkungan kerja sendiri mempunyai dua dimensi, yaitu dimensi fisik (pewarnaan ruangan, pencahayaan, kebersihan, tata ruang,dll) dan dimensi non fisik (kesejahteraan pegawai, suasana kerja, hubungan antar pegawai). Organisasi harus mampu menyediakan kedua dimensi tersebut dalam keadaan baik sehingga mampu membuat para pegawai untuk tetap bekerja dengan produktif dan saling bekerja sama antar pegawai maupun dengan pimpinan untuk mencapai tujuan organisasi.

Menurut Agus Dwiyanto, (2017:47) Konsep kinerja adalah penilaian kinerja yang merupakan suatu kegiatan yang sangat penting karena dapat digunakan sebagai ukuran keberhasilan suatu organisasi dalam mencapai misinya. Untuk organisasi pelayanan publik, 
informasi mengenai kinerja tentu sangat berguna untuk menilai seberapa jauh pelayanan yang diberikan oleh organisasi itu memenuhi harapan dan memuaskan pengguna jasa.

Pada dasarnya kinerja menekankan apa yang dihasilkan dari fungsi-fungsi suatu pekerjaan atau apa yang keluar (out-come). Bila diperhatikan lebih lanjut apa yang terjadi dalam sebuah pekerjaan atau jabatan adalah suatu proses yang mengolah in-put menjadi out-put (hasil kerja). Penggunaan indikator kunci untuk mengukur hasil kerja individu, sumber dari fungsi-fungsi yang diterjemahkan dalam kegiatan/tindaan dengan landasan standar yang jelas dan tertulis.

\section{LANDASAN TEORI}

\section{I Lingkungan Kerja}

Menurut Sedarmayati (2001:2I), mendefinisikan lingkungan kerja adalah keseluruhan alat perkakas dan bahan yang dihadapi, lingkungan sekitarnya di mana seseorang bekerja, metode kerjanya, serta pengaturan kerjanya baik sebagai perseorangan maupun sebagai kelompok. Sementara itu menurut Saydam (2000:226), yang mendefinisikan lingkungan kerja sebagai keseluruhan sarana prasarana kerja yang ada disekitar pegawai yang sedang melaksanakan pekerjaan yang dapat mempengaruhi pelaksanaan pekerjaan itu sendiri.

Berdasarkan pendapat di atas dapat disimpulkan bahwa lingkungan kerja adalah suatu kondisi dimana para pegawai bekerja dalam suatu organisasi yang dapat mempengaruhi kondisi fisik dan psikologi pegawai baik secara langsung maupun tidak langsung sehingga lingkungan kerja dapat dikatakan baik apabila pegawai dapat bekerja dengan optimal, tenang dan produktivitasnya tinggi.

\subsection{Indikator Lingkungan Kerja}

Secara garis besar, jenis lingkungan kerja terbagi menjadi 2 yakni lingkungan kerja fisik dan lingkungan kerja non fisik.

\section{Lingkungan Kerja Fisik}

Lingkungan kerja fisik adalah semua yang terdapat disekitar tempat kerja yang dapat mempengaruhi pegawai baik secara langsung maupun tidak langsung (Sedarmayanti, 200 I: 21).

Lingkungan kerja fisik dapat dibagi dalam dua kategori, yakni :

a. Lingkungan yang langsung berhubungan dengan karyawan (Seperti: pusat kerja, kursi, meja dan sebagainya)

b. Lingkungan perantara atau lingkungan umum dapat juga disebut lingkungan kerja yang mempengaruhi kondisi manusia, misalnya temperatur, kelembaban, sirkulasi udara, pencahayaan, kebisingan, getaran mekanis, bau tidak sedap, warna, dan lain-lain

2. Lingkungan Kerja Non Fisik

Menurut Sedarmayanti (2001:3I), menyatakan bahwa "lingkungan kerja non fisik adalah semua keadaan yang terjadi yang berkaitan dengan hubungan kerja, baik dengan atasan maupun dengan sesama rekan kerja ataupun hubungan dengan bawahan".

Setiap pegawai harus membina hubungan yang harmonis baik dengan sesama pegawai maupun dengan para atasannya, mampu berkomunikasi dalam sebuah team kerja dan bersikap ramah. Akibat dengan adanya hubungan pegawai yang baik maka para pegawai akan dapat menghindari diri dari konflik-konflik yang mungkin timbul di dalam organisasi tersebut (Agus Ahyari, 1994: 192). Berdasarkan pendapat para ahli di atas, dapat disimpulkan bahwa indikator lingkungan kerja non fisik terbagi menjadi dua yaitu:

a) Hubungan antar karyawan;

b) Hubungan dengan atasan.

\subsection{Kinerja Pegawai}

Secara etimologis, kinerja adalah sebuah kata yang dalam bahasa Indonesia berasal dari kata dasar "kerja" yang menerjemahkan kata dari bahasa asing prestasi, bisa pula berarti hasil kerja. Sehingga pengertian kinerja dalam organisasi merupakan jawaban dari berhasil atau tidaknya tujuan organisasi yang telah 
ditetapkan. Para pegawai negri sipil sering tidak memperhatikan kecuali sudah amat buruk atau segala sesuatu jadi serba salah. Terlalu sering para pegawai tidak mengetahui betapa buruknya kinerja telah merosot sehingga organisasi dalam suatu instansi pemerintahan menghadapi krisis yang serius.

\section{Menurut Agus Dwiyanto (2017:47) Konsep}

kinerja adalah penilaian kinerja yang merupakan suatu kegiatan yang sangat penting karena dapat digunakan sebagai ukuran keberhasilan suatu organisasi dalam mencapai misinya. Untuk organisasi pelayanan publik, informasi mengenai kinerja tentu sangat berguna untuk menilai seberapa jauh pelayanan yang diberikan oleh organisasi itu memenuhi harapan dan memuaskan pengguna jasa.

Pendapat lain yang berkaitan dengan pengertian kinerja, diantaranya menurut Mathis dan Jackson dalam bukunya yang berjudul Manajemen Sumber Daya Manusia yang dimaksud dengan kinerja adalah apa yang dilakukan atau tidak dilakukan pegawai yang meliputi elemen kuantitas hasil, kualitas hasil, ketepatan waktu dari hasil, kehadiran, dan kemampuan bekerja sama. (Mathis dan Jackson 2006:378) Lain halnya menurut Mangkunegara dalam bukunya yang berjudul Manajemen Sumber Daya Manusia yang dimaksud dengan kinerja adalah prestasi kerja atau hasil kerja baik kualitas maupun kuantitas yang dicapai SDM per satuan periode waktu dalam melaksanakan tugas kerjanya dengan tanggung jawab yang diberikan kepadanya ( Mangkunegara, 2000: 2).

Berdasarkan pendapat di atas dapat disimpulkan bahwa pengertian kinerja adalah hasil kerja yang dicapai seseorang pegawai terhadap pelaksanaan tugas yang dinilai berdasarkan pada kriteria atau standar penilaian tertentu. Istilah kinerja sering digunakan untuk menyebut tingkat keberhasilan individu atau kelompok. Sedangkan kinerja bisa diketahui jika individu atau kelompok individu tersebut mempunyai kriteria keberhasilan yang telah ditetapkan.

\subsection{Indikator Kinerja}

Agus Dwiyanto (2017:50) dalam bukunya yang berjudul Mewujudkan Good Governance Melalui Pelayanan Publik menjelaskan bagaimana cara untuk mengukur kinerja birokrasi publik berdasar adanya indikator mengacu pada prinsip-prinsip Good Governance secara lebih lanjut dijelaskan sebagai berikut :

a. Produktivitas

$$
\text { Konsep produktivitas tidak hanya }
$$
mengukur tingkat efisiensi, tetapi juga efektivitas pelayanan. Produktivitas pada umumnya dipahami sebagai rasio antara input dengan output. Konsep produktivitas dirasa terlalu sempit dan kemudian General Accounting Office (GAO) mencoba mengembangkan satu ukuran produktivitas yang lebih luas dengan memasukkan seberapa besar pelayanan publik itu memiliki hasil yang diharapkan sebagai salah satu indikator kinerja yang penting.

b. Kualitas Layanan

Isu mengenai kualitas layanan cenderung semakin menjadi penting dalam menjelaskan kinerja organisasi pelayanan publik. Banyak pandangan negatif yang terbentuk mengenai organisasi publik muncul karena ketidakpuasan masyarakat terhadap kualitas layanan yang diterima dari organisasi publik.

c. Responsivitas

Responsivitas adalah kemampuan organisasi untuk mengenali kebutuhan masyarakat, menyusun agenda dan prioritas pelayanan, mengembangkan program-program pelayanan publik sesuai dengan kebutuhan dan aspirasi masyarakat. Secara singkat responsivitas disini menunjuk pada keselarasan antara program dan kegiatan pelayanan dengan kebutuhan dan aspirasi masyarakat. Responsivitas dimasukkan sebagai salah satu indikator kinerja karena responsivitas secara langsung menggambarkan kemampuan organisasi publik dalam menjalankan misi dan tujuannya, terutama untuk memenuhi kebutuhan masyarakat. 
Responsivitas yang rendah ditunjukkan dengan ketidakselarasan antara pelayanan dengan kebutuhan masyarakat. Hal tersebut jelas menunjukkan kegagalan organisasi dalam mewujudkan misi dan tujuan organisasi publik. Organisasi yang memiliki responsivitas rendah dengan sendirinya memiliki kinerja yang jelek pula.

d. Responsibilitas

Responsibilitas menjelaskan apakah pelaksanaan kegiatan organisasi publik itu dilakukan sesuai dengan prinsip-prinsip administrasi yang benar atau sesuai dengan kebijakan organisasi, baik yang eksplisit maupun implisit. Oleh sebab itu, responsibilitas bisa saja pada suatu ketika berbenturan dengan responsivitas.

e. Akuntabilitas

Akuntabilitas Publik menunjuk pada seberapa besar kebijakan dan kegiatan organisasi publik tunduk pada para pejabat public yang dipilih oleh rakyat. Asumsinya adalah bahwa para pejabat politik tersebut karena dipilih oleh rakyat, dengan sendirinya akan selalu merepresentasikan kepentingan rakyat. Dalam konteks ini, konsep dasar akuntabilitas publik dapat digunakan untuk melihat seberapa besar kebijakan dan kegiatan organisasi publik itu konsisten dengan kehendak masyarakat banyak. Kinerja organisasi publik tidak hanya bisa dilihat dari ukuran internal yang dikembangkan oleh organisasi publik atau pemerintah, seperti pencapaian target. Kinerja sebaiknya harus dinilai dari ukuran eksternal, seperti nilai-nilai dan norma yang berlaku dalam masyarakat. Suatu kegiatan organisasi publik memiliki akuntabilitas yang tinggi kalau kegiatan itu dianggap benar dan sesuai dengan nilai dan norma yang berkembang dalam masyarakat. (Agus Dwiyanto 2017 : 50)

\subsection{Hubungan Lingkungan Kerja terhadap Kinerja Pegawai}

Suatu kondisi lingkungan kerja dikatakan baik atau sesuai apabila manusia yang berada didalamnya dapat melaksanakan kegiatannya secara optimal, sehat, aman, dan nyaman. Kesesuaian lingkungan kerja dapat berdampak dalam waktu yang lama, demikian juga dengan lingkungan kerja yang buruk akan mengakibatkan sulitnya memperoleh sistem kerja yang efektif dan efisien.

Ardana (2012:208) mengemukakan bahwa "lingkungan kerja yang aman dan sehat terbukti berpengaruh terhadap produktivitas". Selain itu dikemukakan juga bahwa "kondisi kerja yang menyenangkan dapat mencakup tempat kerja, dan fasilitas-fasilitas bantu yang mempercepat penyelesaian pekerjaan”.

Menurut Mangkunegara (2004:68) lingkungan kerja mempunyai hubungan yang sangat erat terhadap kinerja karyawan, motif berprestasi yang perlu dimiliki oleh karyawan harus ditumbuhkan dari dalam diri sendiri dan dari lingkungan kerja, karena motif berprestasi yang ditumbuhkan dari dalam diri sendiri akan membentuk suatu kekuatan diri dan jika situasi lingkungan kerja turut menunjang maka pencapaian kinerja akan lebih mudah.”

\section{METODOLOGI}

Pada Penelitian ini, penulis menggunakan penelitian kuantitatif deskriptif. Data yang digunakan adalah data primer dan sekunder yang dikumpulkan melalui, observasi, wawancara, dokumentasi dan kuesioner. Sampel yang dijadikan obyek penelitian sebanyak 30 orang. Penelitian ini mempunyai dua varibel yaitu independen (X) Disiplin Kerja dan variabel dependen ( $\mathrm{Y}$ ) Kinerja Pegawai bagian pelatihan kerja dan penempatan tenaga kerja. Teknik pengolahan data dan analisis data yang digunakan skala likert (kuesioner), analisis Regresi Linier Sederhana beserta uji koefisien regresi sederhana (uji t) dengan menggunakan program windows aplikasi 
SPSS statistik versi 25 untuk menguji hasil perhitungan di analisis data tersebut..

Lokasi Dinas Kependudukan dan Pencatatan Sipil yang beralamat di Jalan Pelita Raya No. 305 Kode Pos 737I I, Buntok Kota Dusun Selatan Kabupaten Barito Selatan, Kal-Teng. Teknik pengumpulan data yang digunakan dalam penelitian ini adalah menggunakan Kuesioner.

\section{Analisis Regresi Sederhana}

\section{Regresi linear sederhana}

Rumus regresi linear sederhana sebagi berikut: $Y=a+b X$

Rumus untuk mencari koefisien a dan b digunakan rumus :

$$
\begin{gathered}
a=\frac{\left(\sum y\right)\left(\sum x^{2}\right)-\left(\sum x\right)\left(\sum x y\right)}{n \sum x^{2}-\left(\sum y\right)^{2}} \\
b=\frac{n \cdot\left(\sum x y\right)-\left(\sum x\right)\left(\sum y\right)}{n \cdot \sum x^{2}-\left(\sum y x\right)^{2}}
\end{gathered}
$$

\section{Keterangan:}

$Y=$ Variabel dependen (Kinerja Pegawai)

$X=$ Variabel independen (Lingkungan Kerja)

a $=$ Konstanta (nilai $Y$ apabila $X=0$ )

$\mathrm{b}=$ Koefisien regresi (nilai peningkatan ataupun penurunan)

\section{Uji T}

Rencana pengajian hipotesis yang di uji pada penelitian ini adalah mengenai ada tidaknya pengaruh yang signifikan antara variabel-variabel yang diteliti, signifikan artinya berarti atau berpengaruh yang terjadi dapat berlaku untuk populasi (dapat digeneralisasikan), maka demikian :

I. Jika t hitung $\leq \mathrm{t}$ table maka $\mathrm{H}_{0}$ diterima , artinya Lingkungan Kerja tidak berpengaruh terhadap Kinerja Pegawai.

2. Jika $\mathrm{t}$ hitung $>\mathrm{t}$ table maka $\mathrm{H}_{0}$ ditolak, artinya Lingkungan Kerja berpengaruh terhadap Kinerja Pegawai.

Rumus t hitung pada analisis regresi adalah :

\section{Pengujian Reliabilitas}

Uji Reliabilitas di gunakan untuk mengetahui konsistensi alat ukur, apakah alat ukur yang di gunakan dapat di andalkandan tetap konsisten jika pengukuran tersebut di ulang, dalam penelitian ini di gunakan metode Cronbach's Alpa. Metode Cronbach's Alpa sangat cocok di gunakan pada sekor berbentuk skala (misalkan 1-4, 1-5). Rumus Reliabilitas dengan metode Alpa (Arikunto 2002:II2).

\section{PEMBAHASAN}

\section{Rekapitulasi Jawaban kuisioner}

Rekapitulasi Hasil jawaban kuisioner yang di dapat dari 30 responden Pegawai Dinas Kependudukan dan Pencatatan Buntok yang terdiri dari variabel Lingkungan Kerja (X) dan Kinerja Pegawai (Y) Di masukkan dalam tabel rekapitulasi jawaban.

Rekapitulasi Hasil Uji Validitas dan Reabilitas Untuk Untuk Mengukur Pengaruh Lingkungan Kerja terhadap kinerja pegawai pada dinas kependudukan dan pencatatan sipil kabupaten barito selatan tahun 2021 .

\section{Hasil Uji Validitas}

I. Hasil Uji Validitas Lingkungan Kerja (X)

Tabel 4. I I

Hasil Uji Validitas Variabel (X)

\begin{tabular}{|c|c|c|c|}
\hline $\begin{array}{c}\text { Item } \\
\text { Pertanyaa } \\
\mathbf{n}\end{array}$ & $\begin{array}{c}\text { Skor } \\
\text { Tota } \\
\text { I }\end{array}$ & $\begin{array}{c}\text { Validita } \\
\mathbf{s}\end{array}$ & $\begin{array}{c}\text { Keteranga } \\
\mathbf{n}\end{array}$ \\
\hline Item I / PI & 0,7 I8 & 0,36 I & Valid \\
\hline Item 2 / P2 & 0,4 I9 & 0,36 I & Valid \\
\hline Item 3 / P3 & 0,74 I & 0,36 I & Valid \\
\hline Item 4 / P4 & 0,444 & 0,36 I & Valid \\
\hline Item 5 / P5 & 0,742 & 0,36 I & Valid \\
\hline Item 6 / P6 & 0,5 I0 & 0,36 I & Valid \\
\hline Item 7 / P7 & 0,635 & 0,36 I & Valid \\
\hline Item 8 / P8 & 0,436 & 0,36 I & Valid \\
\hline Item 9 / P9 & 0,635 & 0,36 I & Valid \\
\hline Item I0 / & 0,4 I4 & 0,36 I & Valid \\
PI0 & & \multicolumn{2}{|l}{} \\
\hline
\end{tabular}

* Data Primer di buat oleh peneliti pada bulan Pebruari202I

Dari output variabel $(X)$ dapat diketahui nilai korelasi antara skor item dengan skor total. Kemudian di cari pada nilai $r_{\text {tabel }}(n=30)$ pada tingkat 0,05 atau $5 \%$ dalam tabel distribusi nilai $r_{\text {tabel. }}$ Nilai dari $(n=30-2=$ 28) pada nilai $r$ tabel dengan uji 2 sisi pada tingkat signifikan dan jumlah responden $(n=30)$ adalah $0,36 \mathrm{I}$. Maka dapat disimpulkan bahwa semua item variabel $(X)$ dinyatakan valid, karena nilai skor total semua item lebih dari 0,361 . 
2. Hasil Uji Validitas Kinerja Pegawai (Y)

Tabel 4.12

Hasil Uji Validitas Variabel (Y)

\begin{tabular}{|c|c|c|c|}
\hline $\begin{array}{c}\text { Item } \\
\text { Pertanyaa } \\
\mathbf{n}\end{array}$ & $\begin{array}{c}\text { Skor } \\
\text { Tota } \\
\text { I }\end{array}$ & $\begin{array}{c}\text { Validita } \\
\mathbf{s}\end{array}$ & $\begin{array}{c}\text { Keteranga } \\
\mathbf{n}\end{array}$ \\
\hline Item I / PI & 0,699 & 0,36 I & Valid \\
\hline Item 2 / P2 & 0,435 & 0,36 I & Valid \\
\hline Item 3 / P3 & 0,548 & 0,36 I & Valid \\
\hline Item 4 / P4 & 0,620 & 0,36 I & Valid \\
\hline Item 5 / P5 & 0,453 & 0,36 I & Valid \\
\hline Item 6 / P6 & 0,53 I & 0,36 I & Valid \\
\hline Item 7 / P7 & 0,7 I8 & 0,36 I & Valid \\
\hline Item 8 / P8 & 0,405 & $0,36 I$ & Valid \\
\hline Item 9 / P9 & 0,550 & $0,36 I$ & Valid \\
\hline Item I0 / & 0,65 I & $0,36 I$ & Valid \\
PI0 & & & \\
\hline Data Primer di buat oleh peneliti pada bulan
\end{tabular}

Data Primer di buat oleh peneliti pada bulan Pebruari202I

Dari output variabel $(Y)$ dapat diketahui nilai korelasi antara skor item dengan skor total. Kemudian di cari pada nilai $r_{\text {tabel }}(n=30)$ pada tingkat 0,05 atau $5 \%$ dalam tabel distribusi nilai $r$ tabel. Nilai dari $(n=30-2=28)$ pada nilai $r_{\text {tabel }}$ dengan uji 2 sisi pada tingkat signifikan dan jumlah responden (n = 30) adalah 0,36I. Maka dapat disimpulkan bahwa semua item variabel $(Y)$ valid, karena nilai skor total semua item lebih dari 0,36I.

\section{Hasil Uji Reliabilitas}

Instrumen yang reliabel adalah instrumen yang bila digunakan beberapa kali untuk mengukur objek yang sama, sehingga akan menghasilkan data yang sama. Butir kuesioner dikatakan reliabel (layak) jika cronbach's alpha > 0,60 dan dikatakan tidak reliabel jika cronbach's alpha $<0,60$.

I. Hasil Uji Reliabilitas Lingkungan Kerja (X)

Tabel 4.13

Hasil Uji Reliabilitas Variabel (X)

\begin{tabular}{|c|c|c|}
\hline $\begin{array}{c}\text { Item } \\
\text { Pertanyaan }\end{array}$ & $\begin{array}{c}\text { Cronbach's } \\
\text { Alpha If } \\
\text { Item } \\
\text { Deleted }\end{array}$ & Keterangan \\
\hline Item I / PI & 0,728 & Reliabel \\
\hline Item 2 / P2 & 0,775 & Reliabel \\
\hline Item 3 / P3 & 0,723 & Reliabel \\
\hline Item 4 / P4 & 0,77 I & Reliabel \\
\hline Item 5 / P5 & 0,723 & Reliabel \\
\hline Item 6 / P6 & $0,76 I$ & Reliabel \\
\hline
\end{tabular}

\begin{tabular}{|c|c|c|}
\hline Item 7 / P7 & 0,742 & Reliabel \\
\hline Item 8 / P8 & 0,770 & Reliabel \\
\hline Item 9 / P9 & 0,742 & Reliabel \\
\hline Item 10 / PI0 & 0,777 & Reliabel \\
\hline
\end{tabular}

\begin{tabular}{|r|r|}
\hline \multicolumn{2}{|c|}{ Reliability Statistics } \\
\hline $\begin{array}{c}\text { Cronbach's } \\
\text { Alpha }\end{array}$ & N of Items \\
\hline .772 & 10 \\
\hline
\end{tabular}

Dari hasil uji reliabilitas, di dapat nilai Cronbach's Alpha sebesar 0,772. Jika cronbach's alpha > 0,60 maka kuesioner dianggap konsisten atau reliabel. Sedangkan jika alpha $<0,60$ maka kuesioner di anggap tidak konsisten.

Maka dapat disimpulkan nilai cronsbach's alpha 0,772 >0,60 sehingga dapat dikatakan bahwa kuesioner tersebut reliabel atau konsisten.

2. Hasil Uji Reliabilitas Kinerja Pegawai (Y)

Tabel 4.14

Hasil Uji Reliabilitas Variabel (Y)

\begin{tabular}{|c|c|c|}
\hline $\begin{array}{c}\text { Item } \\
\text { Pertanyaan }\end{array}$ & $\begin{array}{c}\text { Cronbach's } \\
\text { Alpha If } \\
\text { Item } \\
\text { Deleted }\end{array}$ & Keterangan \\
\hline Item I / PI & 0,7 I3 & Reliabel \\
\hline Item 2 / P2 & 0,758 & Reliabel \\
\hline Item 3 / P3 & 0,740 & Reliabel \\
\hline Item 4 / P4 & 0,728 & Reliabel \\
\hline Item 5 / P5 & 0,755 & Reliabel \\
\hline Item 6 / P6 & 0,743 & Reliabel \\
\hline Item 7 / P7 & 0,710 & Reliabel \\
\hline Item 8 / P8 & 0,762 & Reliabel \\
\hline Item 9 / P9 & 0,740 & Reliabel \\
\hline Item I0 / & 0,722 & Reliabel \\
PI0 & & \\
\hline
\end{tabular}

\begin{tabular}{|r|r|}
\hline \multicolumn{2}{|c|}{ Reliability Statistics } \\
\hline $\begin{array}{c}\text { Cronbach's } \\
\text { Alpha }\end{array}$ & N of Items \\
\hline .758 & 10 \\
\hline
\end{tabular}

Uji Regresi Linier Sederhana

Tabel 4.I5

Rekapitulasi Data Variabel (X) dan Variabel (Y)

\begin{tabular}{|c|c|c|c|c|c|}
\hline $\begin{array}{c}\text { Res } \\
\text { po } \\
\text { nden }\end{array}$ & $\mathbf{X}$ & $\mathbf{Y}$ & $\mathbf{X Y}$ & $\mathbf{X}^{2}$ & $\mathbf{Y}^{2}$ \\
\hline I & 44 & 42 & 1848 & 1936 & 1764 \\
\hline 0 & 49 & 49 & 2401 & 2401 & 2401 \\
\hline 3 & 43 & 41 & 1763 & 1849 & 1681 \\
\hline 4 & 42 & 46 & 1932 & 1764 & 2116 \\
\hline
\end{tabular}




\begin{tabular}{|c|c|c|c|c|c|}
\hline 5 & 50 & 46 & 2300 & 2500 & 2116 \\
\hline 6 & 45 & 41 & 1845 & 2025 & 1681 \\
\hline 7 & 42 & 49 & 2058 & 1764 & 2401 \\
\hline 8 & 45 & 42 & 1890 & 2025 & 1764 \\
\hline 9 & 42 & 41 & 1722 & 1764 & 1681 \\
\hline 10 & 45 & 44 & 1980 & 2025 & 1936 \\
\hline II & 46 & 45 & 2070 & 2116 & 2025 \\
\hline 12 & 48 & 46 & 2208 & 2304 & 2116 \\
\hline 13 & 43 & 44 & 1892 & 1849 & 1936 \\
\hline 14 & 42 & 40 & 1680 & 1764 & 1600 \\
\hline 15 & 43 & 43 & 1849 & 1849 & 1849 \\
\hline 16 & 47 & 42 & 1974 & 2209 & 1764 \\
\hline 17 & 49 & 49 & 2401 & 2401 & 2401 \\
\hline 18 & 49 & 46 & 2254 & 2401 & 2116 \\
\hline 19 & 47 & 47 & 2209 & 2209 & 2209 \\
\hline 20 & 49 & 49 & 2401 & 2401 & 2401 \\
\hline 21 & 40 & 45 & 1800 & 1600 & 2025 \\
\hline 22 & 47 & 49 & 2303 & 2209 & 2401 \\
\hline 23 & 48 & 45 & 2160 & 2304 & 2025 \\
\hline 24 & 49 & 47 & 2303 & 2401 & 2209 \\
\hline 25 & 49 & 48 & 2352 & 2401 & 2304 \\
\hline 26 & 48 & 49 & 2352 & 2304 & 2401 \\
\hline 27 & 46 & 46 & 2116 & 2116 & 2116 \\
\hline 28 & 45 & 45 & 2025 & 2025 & 2025 \\
\hline 29 & 48 & 48 & 2304 & 2304 & 2304 \\
\hline 30 & 45 & 47 & 2115 & 2025 & 2209 \\
\hline$\Sigma=$ & 1375 & 1361 & 62507 & 63245 & 61977 \\
\hline
\end{tabular}

Rumus Regresi Linier Sederhana :

\section{$\mathbf{Y}=\mathbf{a}+\mathbf{b} \mathbf{X}$}

Kemudian untuk mencari koefisien a dan b dengan rumus :

$$
\mathrm{b}=\frac{\mathrm{n} \cdot \sum \mathrm{xy}-\sum \mathrm{x} \cdot \sum \mathrm{y}}{\mathrm{n} \cdot \sum \mathrm{x}^{2}-\left(\sum \mathrm{x}\right)^{2}}
$$

$\mathrm{b}=\frac{30.62507-1375.1361}{30.63245-(1375)^{2}}$

$\mathrm{b}=\frac{1875210-1871375}{1897350-1375.1375}$

$\mathrm{b}=\frac{1875210-1871375}{1897350-1890625}$

$\mathrm{b}=\frac{3835}{6725}$

$\mathrm{b}=0,570260223 \approx 0,570$

$\mathrm{a}=\frac{\sum \mathrm{y}-\mathrm{b} \cdot\left(\sum \mathrm{x}\right)}{\mathrm{n}}$ $\mathrm{a}=\frac{1361-0,570260223 \cdot 1375}{30}$

$\mathrm{a}=\frac{1361-784,107807}{30}$

$\mathrm{a}=\frac{576,892193}{30}$

$\mathrm{a}=19,2297398 \approx 19,230$

Maka persamaan regresinya adalah :

$\mathrm{Y}=\mathrm{a}+\mathrm{bX}$

$\longrightarrow Y=19,230+$

$0,570 \times$

Arti persamaan $Y=19,320+0,570 \times$ tersebut adalah nilai (a) sebesar 19,320. Artinya jika pengaruh Lingkungan Kerja (X) nilai skornya adalah 0, maka Kinerja Pegawai (Y) nilai skornya sebesar 0,570. Kemudian koefisien regresi (b) variabel Lingkungan Kerja (X) sebesar 19,320 artinya jika nilai skor Lingkuan Kerja mengalami kenaikan sebanyak I kali, maka Kinerja Pegawai (Y) akan mengalami peningkatan sebesar 19,230 serta koefisien bernilai positif artinya terjadi hubungan positif antara Lingkungan Kerja (X) dengan Kinerja Pegawai (Y).

Dari persamaan tersebut, hasil persamaan regresi sederhana berarti bahwa :

I. Konstanta sebesar 19,230 jika variable Lingkungan Kerja dimasukkan tetap, maka kinerja pegawai akan meningkatkan sebesar 19,230.

2. Nilai koefisien regresi untuk variable Lingkungan Kerja (X) pada persamaan regresi menunjukkan nilai positif 0,570, dapat di artikan bahwa jika variabel Lingkungan Kerja meningkat 5,70\%.

3. Dari hasil pengujian koefisien regresi diperoleh kesimpulan bahwa Lingkungan Kerja berpengaruh terhadap peningkatan Kinerja Pegawai.

Lingkungan kerja yang nyaman akan berdampak langsung terhadap kinerja pegawainya, terutama dalam hal penyelesaian pekerjaan yang diberikan. Data hasil perhitungan rentang skala per indikator lingkungan kerja dan kinerja karyawan terhadap 30 responden yang ada pada Dinas Kependudukan dan Pencatatan Sipil Kabupaten Barito Selatan menunjukan bahwa lingkungan kerja dan kinerja pegawai masuk ke dalam kategori sangat baik. 
Hasil tersebut juga sesuai dengan jawaban narasumber yang peneliti ajukan saat sesi wawancara terhadap Bapak Drs. Nyamei Tumbai selaku Kepala Dinas Kependudukan dan Pencatatan Sipil Kabupaten Barito Selatan yang menjawab sebagai berikut:

"Drs. Nyamei Tumbai mengatakan, Lingkungan Kerja sangat berpengaruh terhadap Kinerja Pegawai dari sisi ruangan, tempat duduk, meja, suasana, bahkan setiap kepala bidang ataupun kepala seksi harus memiliki ruangannya masingmasing karena lingkungan kerja akan mempengaruhi Kinerja yang dihasilkan oleh pegawai."

Kemudian pendapat tersebut juga sama dengan keterangan dari Bapak Didik Suski Asrianto pegawai Dinas Kependudukan dan Pencatatan Sipil Kabupaten Barito Selatan selaku Operator SIAK (Sistem Informasi Administrasi Kependudukan) yaitu :

“Didik Suski Asrianto mengatakan setuju, secara umum untuk lingkungan kerja sudah pasti sedikit banyaknya mempunyai pengaruh terhadap kinerja pegawai terutama ruangan tempat kerja yang kurang tertata sangat mempengaruhi sekali gairah yang dapat memunculkan kejenuhan kerja setiap pegawainya."

Kemudian pendapat tersebut juga senada dengan keterangan dari Farah Yunisa, S.H pegawai Dinas Kependudukan dan Pencatatan Sipil Kabupaten Barito Selatan selaku Pengadministrasi Umum bagian Sekretariat yaitu :

" Farah Yunisa, S.H mengatakan, tentu sangat mempengaruhi. Pada Dinas Kependudukan dan Pencatatan Sipil Kabupaten Barito Selatan salah satu sistim kerja nya berbasis Online contohnya seperti mengentry data masyarakat, pencetakan KK, KTP, Akta, dll. Maka keterkaitan dengan jaringan internet dan listrik sangat vital, apabila salah satu dari kedua hal tersebut ataupun keduanya bermasalah maka akan berpengaruh terhadap pelayanan masyarakat."

Berdasarkan hasil wawancara dari 3 narasumber tersebut dapat ditarik kesimpulan bahwa lingkungan kerja sangat mempengaruhi aktivitas pekerjaan para pegawai pada Kantor Dinas Kependudukan dan Pencatatan Sipil Kabupaten Barito Selatan. Hasil tersebut juga senada dengan 2 hasil penelitian terdahulu yang peneliti ambil yaitu:

\section{Rodi Ahmad Ginanjar (20/3) Terdapat} Hubungan yang positif dan signifikan antara lingkungan kerja dengan kinerja karyawan pada Dinas Pendidikan, Pemuda, dan Olahraga Kabupaten Sleman. Kinerja karyawan pada Dinas Pendidikan, Pemuda, dan Olahraga Kabupaten Sleman 4I,3\% dipengaruhi oleh lingkungan kerja yang ada. Dan; Ramma Indra Pramuji (2017) Terdapat pengaruh yang positif dan signifikan antara lingkungan terhadap kinerja karyawan pada Dinas Kepemudaan dan Olahraga Kabupaten Indramayu. Disatukan dengan teori utama dalam penelitian ini, yaitu:

"Lingkungan kerja menurut Sedarmayati merupakan keseluruhan alat perkakas dan bahan yang dihadapi, lingkungan sekitar dimana seseorang bekerja, metode kerjanya, serta pengaturan kerjanya baik sebagai perseorangan maupun sebagai kelompok.”

Artinya Lingkungan Kerja tidak hanya membahas tentang tempat maupun hanya ruangan dalam bekerja akan tetapi juga menyangkut hubungan para pegawai serta peralatan yang digunakan dalam melaksanakan pekerjaan, metode kerjanya yang dapat dinilai dari hasil kinerja pegawai tersebut dalam menyelesaikan pekerjaannya.

Menurut Agus Dwiyanto (2017 : 47) konsep kinerja adalah :

"Penilaian Kinerja merupakan suatu kegiatan yang sangat penting karena dapat digunakan sebagai ukuran keberhasilan suatu organisasi dalam mencapai misinya. Untuk organisasi pelayanan publik, informasi mengenai kinerja tentu sangat berguna untuk menilai seberapa jauh pelayanan yang diberikan oleh organisasi itu untuk memenuhi harapan dan memuaskan penggunaan jasa. Dengan melakukan penilaian terhadap kinerja, maka upaya untuk memperbaiki kinerja bisa dilakukan secara lebih terarah dan sistematis."

Artinya berdasarkan pendapat ahli di atas dapat disimpulkan bahwa dengan baiknya kualitas kinerja yang di hasilkan oleh pegawai pada Dinas Kependudukan dan Pencatatan Sipil Kabupaten Barito Selatan maka akan memberikan keberhasilan dalam mencapai misi dari Kantor Dinas Kependudukan dan Pencatatan Sipil Kabupaten Barito Selatan. Kualitas kinerja seorang pegawai sendiri dapat dilihat dari berbagai aspek, yaitu kuantitas dan kualitas dari hasil pekerjaannya yang dinilai 
sudah cukup bagus terlihat dari jarangnya terdapat keluhan dari masyarakat dengan hasil kerja para pegawai pada Dinas Kependudukan dan Pencatatan Sipil Kabupaten Barito Selatan, dari hasil pengisian kuesioner kinerja dapat terlihat bahwa sebagian besar pegawai sudah mampu bekerja dengan optimal, ketepatan waktu dari hasil pekerjaan yang sudah dapat dinilai cukup baik, dan kemampuan bekerja sama dengan pegawai lainnya juga sudah cenderung baik terlihat pada saat mengerjakan tugas yang diberikan para pegawai mampu untuk saling bekerja sama dalam menyelesaikan pekerjaan yang telah diberikan.

Dari hasil dari penelitian ini, serta hasil wawancara, didukung dua teori utama yang peneliti gunakan dan dibuktikankan dari dua hasil penelitian terdahulu yang peneliti ambil sebagai bahan perbandingan dapat disimpulkan bahwa Lingkungan Kerja dapat meningkatkan Kinerja Pegawai. Sehingga Lingkungan Kerja dapat memberikan kontribusi yang bagus dan positif terhadap Kinerja Pegawai.

Dari hasil pengamatan dan observasi peneliti juga setuju bahwa Lingkungan Kerja sangat mempengaruhi Kinerja Pegawai pada Kantor Dinas Kependudukan dan Pencatatan Sipil Kabupaten Barito Selatan hal ini dapat terlihat pada saat pegawai sedang sibuk melakukan pekerjaannya di ruangan yang berbeda-beda sesuai dengan pekerjaannya masing-masing, misalkan pembuatan KTP yang dilakukan khusus diruangan untuk membuat KTP, begitu juga dengan ruangan untuk pembuatan Kartu Keluarga yang juga di pisahkan dengan ruangan pembuatan Akta hal ini dilakukan agar Kinerja Pegawai lebih fokus dengan hasil yang maksimal menyesuaikan dengan pembagian kerja atau tugas perbagian sesuai dengan pekerjaannya masing-masing serta pentingnya kelengkapan peralatan kantor yang harus tersedia begitu juga dengan blangko pendaftaran dan blangko untuk pembuatan Akta, KTP, dan Kartu Keluarga yang harus selalu tersedia di Kantor Dinas Kependudukan dan Pencatatan Sipil Kabupaten Barito Selatan.
Pengaruh yang signifikan antara variable Lingkungan Kerja terhadap Kinerja Pegawai dapat terlihat dari hasil jawaban wawancara kepada Kepala Dinas Kependudukan dan Pencatatan Sipil Kabupaten Barito Selatan yang mengatakan keinginannya untuk mengubah bangunan Kantor Dinas Kependudukan dan Pencatatan Sipil Kabupaten Barito Selatan seperti menghilangan sekat/dinding pembatas pada ruangan dan menggantinya dengan menggunakan kaca transparan agar dapat dengan mudah memonitoring serta mengawasi kinerja para pegawai dan memudahkan untuk pengevaluasian, pengendalian pelaksaan pencatatan sipil pada Kantor Dinas Kependudukan dan Pencatatan Sipil Kabupaten Barito Selatan.

Dari definisi dan hasil analisis regresi sederhana tersebut diatas maka variable $(\mathrm{X})$ Lingkungan Kerja dengan indikator Lingkungan Kerja Fisik, keseluruhan alat perkakas dan bahan yang dihadapi, lingkungan sekitarnya di mana seseorang bekerja, metode kerjanya, serta pengaturan kerjanya baik sebagai perseorangan maupun sebagai kelompok memiliki pengaruh signifikan terhadap Variabel ( $Y$ ) Kinerja Pegawai (indikator Responsibilitas). pada penilaian kinerja yang merupakan suatu kegiatan yang sangat penting karena dapat digunakan sebagai ukuran keberhasilan suatu organisasi dalam mencapai misinya. Untuk organisasi pelayanan publik, informasi mengenai kinerja tentu sangat berguna untuk menilai seberapa jauh pelayanan yang diberikan oleh organisasi itu untuk memenuhi harapan dan memuaskan penggunaan jasa. Dengan melakukan penilaian terhadap kinerja, maka upaya untuk memperbaiki kinerja bisa dilakukan secara lebih terarah dan sistematis. Untuk mewujudkan Misi Dinas Kependudukan dan Pencatatan Sipil Kabupaten Barito Selatan.

\section{Uji Koefisien Regresi Sederhana (uji t)}

Berdasarkan output diperoleh $t_{\text {hitung }}$ yang di olah menggunakan aplikasi SPSS versi 25 sebesar 3,57I (bisa dilihat pada tabel 4.16). Adapun hasil angka perhitungan 
$t_{\text {hitung }}$ manual adalah 3,572 sehingga terdapat selisih koma 0,00 I sesuai dengan tingkat signifikan pada hasil SPSS 25.

Dari hasil pengujian di atas dapat diketahui bahwa $t_{\text {hitung }}>t_{\text {tabel }}(3,572>2,052)$ maka Ho ditolak dan $\mathrm{Ha}$ diterima, artinya bahwa ada pengaruh secara signifikan antara Lingkungan Kerja terhadap Kinerja Pegawai pada Dinas Kependudukan dan Pencatatan Siil Kabupaten Barito Selatan Tahun 202I.

\section{Uji Hipotesis}

\section{Gambar 4.5 Grafik 4.4}

Uji Signifikansi (Uji t)

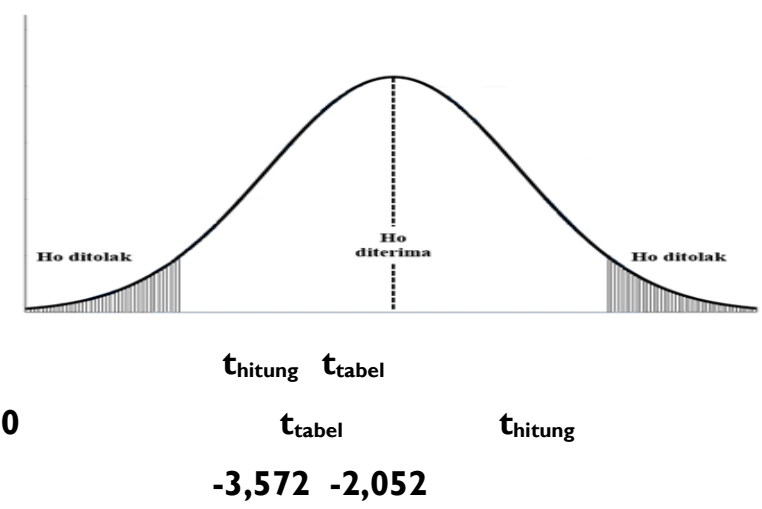

$2,0523,572$

Dari hasil grafik 4.25 di atas diketahui bahwa $t_{\text {hitung }}>t_{\text {tabel }}(3,572>2,052)$ maka Ho ditolak dan $\mathrm{Ha}$ diterima, artinya bahwa ada pengaruh secara signifikan antara Lingkungan Kerja terhadap Kinerja Pegawai pada Dinas Kependudukan dan Pencatatan Sipil Kabupaten Barito Selatan Tahun 202I.

\section{HASIL DAN PEMBAHASAN}

\section{Rekapitulasi Jawaban kuisioner}

Rekapitulasi Hasil jawaban kuisioner yang di dapat dari 30 responden Pegawai Dinas Kependudukan dan Pencatatan Buntok yang terdiri dari variabel Lingkungan Kerja (X) dan Kinerja Pegawai (Y) Di masukkan dalam tabel rekapitulasi jawaban.

Rekapitulasi Hasil Uji Validitas dan Reabilitas Untuk Untuk Mengukur Pengaruh Lingkungan Kerja terhadap kinerja pegawai pada dinas kependudukan dan pencatatan sipil kabupaten barito selatan tahun 2021

\section{Hasil Uji Validitas}

3. Hasil Uji Validitas Lingkungan Kerja (X)

Tabel 4.I I

Hasil Uji Validitas Variabel (X)

\begin{tabular}{|c|c|c|c|}
\hline $\begin{array}{c}\text { Item } \\
\text { Pertanyaan }\end{array}$ & $\begin{array}{c}\text { Skor } \\
\text { Total }\end{array}$ & Validitas & Keterangan \\
\hline Item I / PI & 0,7 I8 & 0,36 I & Valid \\
\hline Item 2 / P2 & $0,4 I 9$ & 0,36 I & Valid \\
\hline Item 3 / P3 & 0,74 I & 0,36 I & Valid \\
\hline Item 4 / P4 & 0,444 & 0,36 I & Valid \\
\hline Item 5 / P5 & 0,742 & 0,36 I & Valid \\
\hline Item 6 / P6 & 0,510 & 0,36 I & Valid \\
\hline Item 7 / P7 & 0,635 & 0,36 I & Valid \\
\hline Item 8 / P8 & 0,436 & 0,36 I & Valid \\
\hline Item 9 / P9 & 0,635 & $0,36 I$ & Valid \\
\hline Item I0 / & $0,4 I 4$ & $0,36 I$ & Valid \\
PI0 & & & \\
\hline
\end{tabular}

*Data Primer di buat oleh peneliti pada bulan Pebruari202I

Dari output variabel $(X)$ dapat diketahui nilai korelasi antara skor item dengan skor total. Kemudian di cari pada nilai $r$ tabel $(n=30)$ pada tingkat 0,05 atau $5 \%$ dalam tabel distribusi nilai $r$ tabel. Nilai dari $(n=30-2=28)$ pada nilai $r$ tabel dengan uji 2 sisi pada tingkat signifikan dan jumlah responden $(n=30)$ adalah $0,36 \mathrm{I}$. Maka dapat disimpulkan bahwa semua item variabel $(X)$ dinyatakan valid, karena nilai skor total semua item lebih dari 0,36I.

4. Hasil Uji Validitas Kinerja Pegawai $(Y)$

Tabel 4.12

Hasil Uji Validitas Variabel (Y)

\begin{tabular}{|c|c|c|c|}
\hline $\begin{array}{c}\text { Item } \\
\text { Pertanyaan }\end{array}$ & $\begin{array}{c}\text { Skor } \\
\text { Total }\end{array}$ & Validitas & Keterangan \\
\hline Item I / PI & 0,699 & 0,36 I & Valid \\
\hline Item 2 / P2 & 0,435 & 0,36 I & Valid \\
\hline Item 3 / P3 & 0,548 & 0,36 I & Valid \\
\hline Item 4 / P4 & 0,620 & 0,36 I & Valid \\
\hline Item 5 / P5 & 0,453 & 0,36 I & Valid \\
\hline Item 6 / P6 & 0,53 I & 0,36 I & Valid \\
\hline Item 7 / P7 & 0,7 I8 & 0,36 I & Valid \\
\hline Item 8 / P8 & 0,405 & 0,36 I & Valid \\
\hline Item 9 / P9 & 0,550 & 0,36 I & Valid \\
\hline Item I0 / & 0,65 I & 0,36 I & Valid \\
PI0 & *Data Primer di buat oleh peneliti pada bulan \\
Pebruari202 I \\
Dari output variabel (Y) dapat diketahui nilai
\end{tabular}

korelasi antara skor item dengan skor total. Kemudian 
di cari pada nilai $r_{\text {tabel }}(n=30)$ pada tingkat 0,05 atau $5 \%$ dalam tabel distribusi nilai $r_{\text {tabel. }}$ Nilai dari $(n=30-2=$ 28) pada nilai $r$ tabel dengan uji 2 sisi pada tingkat signifikan dan jumlah responden $(\mathrm{n}=30)$ adalah 0,36I. Maka dapat disimpulkan bahwa semua item variabel (Y) valid, karena nilai skor total semua item lebih dari $0,36 \mathrm{I}$.

\section{Hasil Uji Reliabilitas}

Instrumen yang reliabel adalah instrumen yang bila digunakan beberapa kali untuk mengukur objek yang sama, sehingga akan menghasilkan data yang sama. Butir kuesioner dikatakan reliabel (layak) jika cronbach's alpha > 0,60 dan dikatakan tidak reliabel jika cronbach's alpha $<0,60$.

3. Hasil Uji Reliabilitas Lingkungan Kerja (X)

Tabel 4.13

Hasil Uji Reliabilitas Variabel (X)

\begin{tabular}{|c|c|c|}
\hline $\begin{array}{c}\text { Item } \\
\text { Pertanyaa } \\
\text { n }\end{array}$ & $\begin{array}{c}\text { Cronbach' } \\
\text { s Alpha If } \\
\text { Item } \\
\text { Deleted }\end{array}$ & $\begin{array}{c}\text { Keteranga } \\
\mathbf{n}\end{array}$ \\
\hline Item I / PI & 0,728 & Reliabel \\
\hline Item 2 / P2 & 0,775 & Reliabel \\
\hline Item 3 / P3 & 0,723 & Reliabel \\
\hline Item 4 / P4 & 0,77 I & Reliabel \\
\hline Item 5 / P5 & 0,723 & Reliabel \\
\hline Item 6 / P6 & 0,761 & Reliabel \\
\hline Item 7 / P7 & 0,742 & Reliabel \\
\hline Item 8 / P8 & 0,770 & Reliabel \\
\hline Item 9 / P9 & 0,742 & Reliabel \\
\hline Item I0 / & 0,777 & Reliabel \\
P I0 & & \\
\hline \multicolumn{2}{|c}{} \\
\hline
\end{tabular}

\begin{tabular}{|r|r|}
\hline \multicolumn{2}{|c|}{ Reliability Statistics } \\
\hline $\begin{array}{c}\text { Cronbach's } \\
\text { Alpha }\end{array}$ & N of Items \\
\hline .772 & 10 \\
\hline
\end{tabular}

Dari hasil uji reliabilitas, di dapat nilai Cronbach's Alpha sebesar 0,772. Jika cronbach's alpha $>$ 0,60 maka kuesioner dianggap konsisten atau reliabel. Sedangkan jika alpha $<0,60$ maka kuesioner di anggap tidak konsisten.

Maka dapat disimpulkan nilai cronsbach's alpha 0,772 >0,60 sehingga dapat dikatakan bahwa kuesioner tersebut reliabel atau konsisten.
4. Hasil Uji Reliabilitas Kinerja Pegawai (Y)

Tabel 4.14

Hasil Uji Reliabilitas Variabel (Y)

\begin{tabular}{|c|c|c|}
\hline $\begin{array}{c}\text { Item } \\
\text { Pertanyaa } \\
\mathbf{n}\end{array}$ & $\begin{array}{c}\text { Cronbach' } \\
\text { s Alpha If } \\
\text { Item } \\
\text { Deleted }\end{array}$ & $\begin{array}{c}\text { Keteranga } \\
\mathbf{n}\end{array}$ \\
\hline Item I / PI & 0,7 I3 & Reliabel \\
\hline Item 2 / P2 & 0,758 & Reliabel \\
\hline Item 3 / P3 & 0,740 & Reliabel \\
\hline Item 4 / P4 & 0,728 & Reliabel \\
\hline Item 5 / P5 & 0,755 & Reliabel \\
\hline Item 6 / P6 & 0,743 & Reliabel \\
\hline Item 7 / P7 & 0,710 & Reliabel \\
\hline Item 8 / P8 & 0,762 & Reliabel \\
\hline Item 9 / P9 & 0,740 & Reliabel \\
\hline Item I0 / & 0,722 & Reliabel \\
PI0 & & \\
\hline
\end{tabular}

Reliability Statistics

Cronbach's

Alpha

.758

$\mathrm{N}$ of Items

10

\section{Uji Regresi Linier Sederhana}

Tabel 4.15

Rekapitulasi Data Variabel (X) dan Variabel (Y)

\begin{tabular}{|c|c|c|c|c|c|}
\hline $\begin{array}{c}\text { Res } \\
\text { po } \\
\text { nden }\end{array}$ & $\mathbf{x}$ & $\mathbf{Y}$ & $\mathbf{X Y}$ & $\mathbf{X}^{2}$ & $\mathbf{Y}^{2}$ \\
\hline 1 & 44 & 42 & 1848 & 1936 & 1764 \\
\hline 0 & 49 & 49 & 2401 & 2401 & 2401 \\
\hline 3 & 43 & 41 & 1763 & 1849 & 1681 \\
\hline 4 & 42 & 46 & 1932 & 1764 & 2116 \\
\hline 5 & 50 & 46 & 2300 & 2500 & 2116 \\
\hline 6 & 45 & 41 & 1845 & 2025 & 1681 \\
\hline 7 & 42 & 49 & 2058 & 1764 & 2401 \\
\hline 8 & 45 & 42 & 1890 & 2025 & 1764 \\
\hline 9 & 42 & 41 & 1722 & 1764 & 1681 \\
\hline 10 & 45 & 44 & 1980 & 2025 & 1936 \\
\hline II & 46 & 45 & 2070 & 2116 & 2025 \\
\hline 12 & 48 & 46 & 2208 & 2304 & 2116 \\
\hline 13 & 43 & 44 & 1892 & 1849 & 1936 \\
\hline 14 & 42 & 40 & 1680 & 1764 & 1600 \\
\hline 15 & 43 & 43 & 1849 & 1849 & 1849 \\
\hline 16 & 47 & 42 & 1974 & 2209 & 1764 \\
\hline 17 & 49 & 49 & 2401 & 2401 & 2401 \\
\hline 18 & 49 & 46 & 2254 & 2401 & 2116 \\
\hline 19 & 47 & 47 & 2209 & 2209 & 2209 \\
\hline 20 & 49 & 49 & 2401 & 2401 & 2401 \\
\hline
\end{tabular}




\begin{tabular}{|c|c|c|c|c|c|}
21 & 40 & 45 & 1800 & 1600 & 2025 \\
\hline 22 & 47 & 49 & 2303 & 2209 & 2401 \\
\hline 23 & 48 & 45 & 2160 & 2304 & 2025 \\
\hline 24 & 49 & 47 & 2303 & 2401 & 2209 \\
\hline 25 & 49 & 48 & 2352 & 2401 & 2304 \\
\hline 26 & 48 & 49 & 2352 & 2304 & 2401 \\
\hline 27 & 46 & 46 & 2116 & 2116 & 2116 \\
\hline 28 & 45 & 45 & 2025 & 2025 & 2025 \\
\hline 29 & 48 & 48 & 2304 & 2304 & 2304 \\
\hline 30 & 45 & 47 & 2115 & 2025 & 2209 \\
\hline$\Sigma=$ & 1375 & 1361 & $\mathbf{6 2 5 0 7}$ & $\mathbf{6 3 2 4 5}$ & $\mathbf{6 1 9 7 7}$ \\
\hline
\end{tabular}

Rumus Regresi Linier Sederhana :

\section{$\mathbf{Y}=\mathbf{a}+\mathbf{b} \mathbf{X}$}

Kemudian untuk mencari koefisien $a$ dan $b$ dengan rumus :

$$
\begin{aligned}
& b=\frac{n \cdot \sum x y-\sum x \cdot \sum y}{n \cdot \sum x^{2}-\left(\sum x\right)^{2}} \\
& b=\frac{30 \cdot 62507-1375 \cdot 1361}{30 \cdot 63245-(1375)^{2}} \\
& b=\frac{1875210-1871375}{1897350-1375 \cdot 1375} \\
& b=\frac{1875210-1871375}{1897350-1890625} \\
& b=\frac{3835}{6725} \\
& b=0,570260223 \approx 0,570 \\
& a=\frac{\sum y-b \cdot\left(\sum x\right)}{n} \\
& a=\frac{1361-0,570260223.1375}{30} \\
& a=\frac{1361-784,107807}{30} \\
& a=\frac{576,892193}{30} \\
& a=19,2297398 \approx 19,230 \\
& \text { Maka persamaan regresinya adalah : } \\
& Y=a+b X \\
& 0,570 \times \quad Y=19,230+
\end{aligned}
$$

Arti persamaan $Y=19,320+0,570 X$ tersebut adalah nilai (a) sebesar 19,320. Artinya jika pengaruh Lingkungan Kerja $(X)$ nilai skornya adalah 0 , maka Kinerja Pegawai (Y) nilai skornya sebesar 0,570. Kemudian koefisien regresi (b) variabel Lingkungan Kerja $(X)$ sebesar 19,320 artinya jika nilai skor
Lingkuan Kerja mengalami kenaikan sebanyak I kali, maka Kinerja Pegawai (Y) akan mengalami peningkatan sebesar 19,230 serta koefisien bernilai positif artinya terjadi hubungan positif antara Lingkungan Kerja (X) dengan Kinerja Pegawai (Y).

Dari persamaan tersebut, hasil persamaan regresi sederhana berarti bahwa :

4. Konstanta sebesar 19,230 jika variable Lingkungan Kerja dimasukkan tetap, maka kinerja pegawai akan meningkatkan sebesar 19,230.

5. Nilai koefisien regresi untuk variable Lingkungan Kerja $(X)$ pada persamaan regresi menunjukkan nilai positif 0,570 , dapat di artikan bahwa jika variabel Lingkungan Kerja meningkat 5,70\%.

6. Dari hasil pengujian koefisien regresi diperoleh kesimpulan bahwa Lingkungan Kerja berpengaruh terhadap peningkatan Kinerja Pegawai.

Lingkungan kerja yang nyaman akan berdampak langsung terhadap kinerja pegawainya, terutama dalam hal penyelesaian pekerjaan yang diberikan. Data hasil perhitungan rentang skala per indikator lingkungan kerja dan kinerja karyawan terhadap 30 responden yang ada pada Dinas Kependudukan dan Pencatatan Sipil Kabupaten Barito Selatan menunjukan bahwa lingkungan kerja dan kinerja pegawai masuk ke dalam kategori sangat baik.

Hasil tersebut juga sesuai dengan jawaban narasumber yang peneliti ajukan saat sesi wawancara terhadap Bapak Drs. Nyamei Tumbai selaku Kepala Dinas Kependudukan dan Pencatatan Sipil Kabupaten Barito Selatan yang menjawab sebagai berikut:

"Drs. Nyamei Tumbai mengatakan, Lingkungan
Kerja sangat berpengaruh terhadap Kinerja
Pegawai dari sisi ruangan, tempat duduk, meja,
suasana, bahkan setiap kepala bidang ataupun
kepala seksi harus memiliki ruangannya masing-
masing karena lingkungan kerja akan
mempengaruhi Kinerja yang dihasilkan oleh
pegawai."
Kemudian pendapat tersebut juga sama dengan keterangan dari Bapak Didik Suski Asrianto pegawai Dinas Kependudukan dan Pencatatan Sipil Kabupaten 
Barito Selatan selaku Operator SIAK (Sistem Informasi

Administrasi Kependudukan) yaitu :

“ Didik Suski Asrianto mengatakan setuju, secara umum untuk lingkungan kerja sudah pasti sedikit banyaknya mempunyai pengaruh terhadap kinerja pegawai terutama ruangan tempat kerja yang kurang tertata sangat mempengaruhi sekali gairah yang dapat memunculkan kejenuhan kerja setiap pegawainya."

Kemudian pendapat tersebut juga senada dengan keterangan dari Farah Yunisa, S.H pegawai Dinas Kependudukan dan Pencatatan Sipil Kabupaten Barito Selatan selaku Pengadministrasi Umum bagian Sekretariat yaitu :

" Farah Yunisa, S.H mengatakan, tentu sangat mempengaruhi. Pada Dinas Kependudukan dan Pencatatan Sipil Kabupaten Barito Selatan salah satu sistim kerja nya berbasis Online contohnya seperti mengentry data masyarakat, pencetakan KK, KTP, Akta, dll. Maka keterkaitan dengan jaringan internet dan listrik sangat vital, apabila salah satu dari kedua hal tersebut ataupun keduanya bermasalah maka akan berpengaruh terhadap pelayanan masyarakat."

Berdasarkan hasil wawancara dari 3

narasumber tersebut dapat ditarik kesimpulan bahwa lingkungan kerja sangat mempengaruhi aktivitas pekerjaan para pegawai pada Kantor Dinas Kependudukan dan Pencatatan Sipil Kabupaten Barito Selatan. Hasil tersebut juga senada dengan 2 hasil penelitian terdahulu yang peneliti ambil yaitu:

Rodi Ahmad Ginanjar (2013) Terdapat Hubungan yang positif dan signifikan antara lingkungan kerja dengan kinerja karyawan pada Dinas Pendidikan, Pemuda, dan Olahraga Kabupaten Sleman. Kinerja karyawan pada Dinas Pendidikan, Pemuda, dan Olahraga Kabupaten Sleman 4I,3\% dipengaruhi oleh lingkungan kerja yang ada. Dan; Ramma Indra Pramuji (2017) Terdapat pengaruh yang positif dan signifikan antara lingkungan terhadap kinerja karyawan pada Dinas Kepemudaan dan Olahraga Kabupaten Indramayu. Disatukan dengan teori utama dalam penelitian ini, yaitu:

“Lingkungan kerja menurut Sedarmayati merupakan keseluruhan alat perkakas dan bahan yang dihadapi, lingkungan sekitar dimana seseorang bekerja, metode kerjanya, serta pengaturan kerjanya baik sebagai perseorangan maupun sebagai kelompok."

Artinya Lingkungan Kerja tidak hanya membahas tentang tempat maupun hanya ruangan dalam bekerja akan tetapi juga menyangkut hubungan para pegawai serta peralatan yang digunakan dalam melaksanakan pekerjaan, metode kerjanya yang dapat dinilai dari hasil kinerja pegawai tersebut dalam menyelesaikan pekerjaannya.

Menurut Agus Dwiyanto (2017 : 47) konsep kinerja adalah :

"Penilaian Kinerja merupakan suatu kegiatan yang sangat penting karena dapat digunakan sebagai ukuran keberhasilan suatu organisasi dalam mencapai misinya. Untuk organisasi pelayanan publik, informasi mengenai kinerja tentu sangat berguna untuk menilai seberapa jauh pelayanan yang diberikan oleh organisasi itu untuk memenuhi harapan dan memuaskan penggunaan jasa. Dengan melakukan penilaian terhadap kinerja, maka upaya untuk memperbaiki kinerja bisa dilakukan secara lebih terarah dan sistematis."

Artinya berdasarkan pendapat ahli di atas dapat disimpulkan bahwa dengan baiknya kualitas kinerja yang di hasilkan oleh pegawai pada Dinas Kependudukan dan Pencatatan Sipil Kabupaten Barito Selatan maka akan memberikan keberhasilan dalam mencapai misi dari Kantor Dinas Kependudukan dan Pencatatan Sipil Kabupaten Barito Selatan. Kualitas kinerja seorang pegawai sendiri dapat dilihat dari berbagai aspek, yaitu kuantitas dan kualitas dari hasil pekerjaannya yang dinilai sudah cukup bagus terlihat dari jarangnya terdapat keluhan dari masyarakat dengan hasil kerja para pegawai pada Dinas Kependudukan dan Pencatatan Sipil Kabupaten Barito Selatan, dari hasil pengisian kuesioner kinerja dapat terlihat bahwa sebagian besar pegawai sudah mampu bekerja dengan optimal, ketepatan waktu dari hasil pekerjaan yang sudah dapat dinilai cukup baik, dan kemampuan bekerja sama dengan pegawai lainnya juga sudah cenderung baik terlihat pada saat mengerjakan tugas yang diberikan para pegawai mampu untuk saling 
bekerja sama dalam menyelesaikan pekerjaan yang telah diberikan.

Dari hasil dari penelitian ini, serta hasil wawancara, didukung dua teori utama yang peneliti gunakan dan dibuktikankan dari dua hasil penelitian terdahulu yang peneliti ambil sebagai bahan perbandingan dapat disimpulkan bahwa Lingkungan Kerja dapat meningkatkan Kinerja Pegawai. Sehingga Lingkungan Kerja dapat memberikan kontribusi yang bagus dan positif terhadap Kinerja Pegawai.

Dari hasil pengamatan dan observasi peneliti juga setuju bahwa Lingkungan Kerja sangat mempengaruhi Kinerja Pegawai pada Kantor Dinas Kependudukan dan Pencatatan Sipil Kabupaten Barito Selatan hal ini dapat terlihat pada saat pegawai sedang sibuk melakukan pekerjaannya di ruangan yang berbeda-beda sesuai dengan pekerjaannya masingmasing, misalkan pembuatan KTP yang dilakukan khusus diruangan untuk membuat KTP, begitu juga dengan ruangan untuk pembuatan Kartu Keluarga yang juga di pisahkan dengan ruangan pembuatan Akta hal ini dilakukan agar Kinerja Pegawai lebih fokus dengan hasil yang maksimal menyesuaikan dengan pembagian kerja atau tugas perbagian sesuai dengan pekerjaannya masing-masing serta pentingnya kelengkapan peralatan kantor yang harus tersedia begitu juga dengan blangko pendaftaran dan blangko untuk pembuatan Akta, KTP, dan Kartu Keluarga yang harus selalu tersedia di Kantor Dinas Kependudukan dan Pencatatan Sipil Kabupaten Barito Selatan.

Pengaruh yang signifikan antara variable Lingkungan Kerja terhadap Kinerja Pegawai dapat terlihat dari hasil jawaban wawancara kepada Kepala Dinas Kependudukan dan Pencatatan Sipil Kabupaten Barito Selatan yang mengatakan keinginannya untuk mengubah bangunan Kantor Dinas Kependudukan dan Pencatatan Sipil Kabupaten Barito Selatan seperti menghilangan sekat/dinding pembatas pada ruangan dan menggantinya dengan menggunakan kaca transparan agar dapat dengan mudah memonitoring serta mengawasi kinerja para pegawai dan memudahkan untuk pengevaluasian, pengendalian pelaksaan pencatatan sipil pada Kantor Dinas Kependudukan dan Pencatatan Sipil Kabupaten Barito Selatan.

Dari definisi dan hasil analisis regresi sederhana tersebut diatas maka variable $(X)$ Lingkungan Kerja dengan indikator Lingkungan Kerja Fisik, keseluruhan alat perkakas dan bahan yang dihadapi, lingkungan sekitarnya di mana seseorang bekerja, metode kerjanya, serta pengaturan kerjanya baik sebagai perseorangan maupun sebagai kelompok memiliki pengaruh signifikan terhadap Variabel (Y) Kinerja Pegawai (indikator Responsibilitas). pada penilaian kinerja yang merupakan suatu kegiatan yang sangat penting karena dapat digunakan sebagai ukuran keberhasilan suatu organisasi dalam mencapai misinya. Untuk organisasi pelayanan publik, informasi mengenai kinerja tentu sangat berguna untuk menilai seberapa jauh pelayanan yang diberikan oleh organisasi itu untuk memenuhi harapan dan memuaskan penggunaan jasa. Dengan melakukan penilaian terhadap kinerja, maka upaya untuk memperbaiki kinerja bisa dilakukan secara lebih terarah dan sistematis. Untuk mewujudkan Misi Dinas Kependudukan dan Pencatatan Sipil Kabupaten Barito Selatan.

\section{Uji Koefisien Regresi Sederhana (uji t)}

Berdasarkan output diperoleh thitung yang di olah menggunakan aplikasi SPSS versi 25 sebesar 3,57। (bisa dilihat pada tabel 4.16). Adapun hasil angka perhitungan $t_{\text {hitung }}$ manual adalah 3,572 sehingga terdapat selisih koma 0,001 sesuai dengan tingkat signifikan pada hasil SPSS 25.

Dari hasil pengujian di atas dapat diketahui bahwa $t_{\text {hitung }}>t_{\text {tabel }}(3,572>2,052)$ maka Ho ditolak dan Ha diterima, artinya bahwa ada pengaruh secara signifikan antara Lingkungan Kerja terhadap Kinerja Pegawai pada Dinas Kependudukan dan Pencatatan Siil Kabupaten Barito Selatan Tahun 202I. 


\section{Uji Hipotesis}

Gambar 4.5 Grafik 4.4
Uji Signifikansi (Uji t)

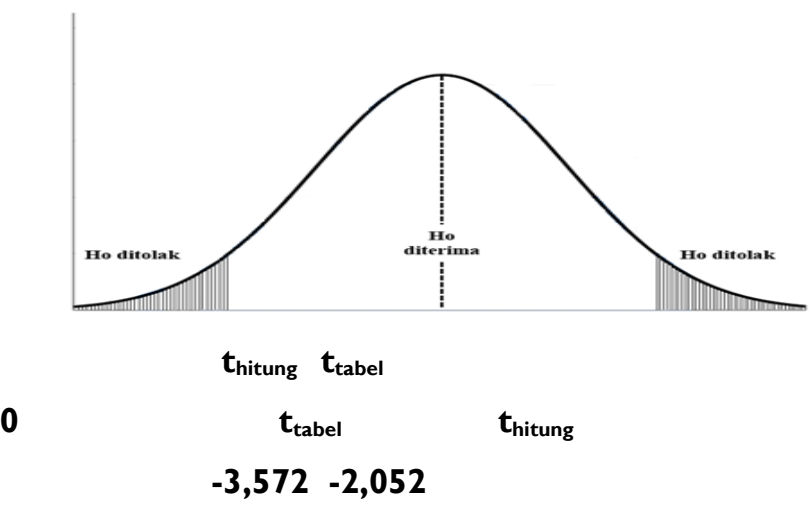

$2,052 \quad 3,572$

Dari hasil grafik 4.25 di atas diketahui bahwa $t_{\text {hitung }}>t_{\text {tabel }}(3,572>2,052)$ maka Ho ditolak dan $\mathrm{Ha}$ diterima, artinya bahwa ada pengaruh secara signifikan antara Lingkungan Kerja terhadap Kinerja Pegawai pada Dinas Kependudukan dan Pencatatan Sipil Kabupaten Barito Selatan Tahun 2021.

\section{KESIMPULAN}

Dari hasil yang diperoleh dalam perhitungan regresi linier sederhana adalah $Y=19,230+0,570 X$ dimana nilai (a) sebesar 19,230 dan nilai koefisien (b) adalah 0,570 . Hasil dari penelitian ini dapat disimpulkan bahwa Lingkungan Kerja dapat meningkatkan Kinerja Pegawai. Sehingga Lingkungan Kerja dapat memberikan kontribusi yang bagus dan positif terhadap Kinerja Pegawai. Dari definisi dan hasil analisis regresi sederhana tersebut diatas maka variable $(X)$ Lingkungan Kerja dengan indikator Lingkungan Kerja Fisik, keseluruhan alat perkakas dan bahan yang dihadapi, lingkungan sekitarnya di mana seseorang bekerja, metode kerjanya, serta pengaturan kerjanya baik sebagai perseorangan maupun sebagai kelompok memiliki pengaruh signifikan terhadap Variabel (Y) Kinerja Pegawai (indikator Responsibilitas). pada penilaian kinerja yang merupakan suatu kegiatan yang sangat penting karena dapat digunakan sebagai ukuran keberhasilan suatu organisasi dalam mencapai misinya. Untuk organisasi pelayanan publik, informasi mengenai kinerja tentu sangat berguna untuk menilai seberapa jauh pelayanan yang diberikan oleh organisasi itu untuk memenuhi harapan dan memuaskan penggunaan jasa. Dengan melakukan penilaian terhadap kinerja, maka upaya untuk memperbaiki kinerja bisa dilakukan secara lebih terarah dan sistematis. Dalam mewujudkan Misi Dinas Kependudukan dan Pencatatan Sipil Kabupaten Barito Selatan.

Kemudian diperoleh hasil pengujian bahwa thitung > ttabel $(3,572>2,052)$ maka Ho ditolak dan Ha diterima, Ho : Tidak terdapat Pengaruh positif lingkungan kerja terhadap kinerja pegawai pada Dinas Kependudukan dan Pencatatan Sipil Kabupaten Barito Selatan Tahun 2021. Dari analisis tersebut bahwa hipotesis diterima Artinya bahwa terdapat Terdapat pengaruh positif lingkungan kerja terhadap kinerja pegawai pada Dinas Kependudukan dan Pencatatan Sipil Kabupaten Barito Selatan Tahun 202I.

\section{SARAN}

Bagi Dinas Kependudukan dan Pencatatan Sipil Kabupaten Barito Selatan, diharapkan dapat tetap menjaga lingkungan kerja yang baik dan masih terlihat dalam keadaan yang bersih dan rapi agar tetap menghasilkan kinerja pegawai yang berproduktifitas tinggi. Atau dengan kata lain memberikan lingkungan yang nyaman dan dapat mempengaruhi kinerja pegawai.

$$
\text { Bagi Pegawai pada kantor Dinas }
$$
Kependudukan dan Pencatatan Sipil Kabupaten Barito Selatan, diharapkan selalu berusaha untuk meningkatkan kualitas diri dalam bekerja serta dapat menerima saran yang diberikan oleh atasan agar dapat menyelesaikan pekerjaannya dengan cepat dan tepat dalam melayani masyarakat. 


\section{REFERENSI}

Dwiyanto, Agus, dkk. (2006). Reformasi Birokrasi Publik di Indonesia.Yogyakarta: Gadjah Mada University Press

Ginanjar Rodi Ahmad (2003). Pengaruh Lingkungan Kerja Terhadap Kinerja Karyawan pada Dinas Pendidikan, Pemuda dan Olahraga Kabupaten Sleman. Skripsi. Yogyakarta: Fakultas IImu Pendidikan Universitas Negeri Yogyakarta

Mahridi MBM. (2019). Pengaruh Budaya Organisasi Islami, Kepemimpinan Islami dan Kompetensi SDM Islami terhadap Kinerja Pegawai di MTsN Barito Selatan Kabupaten Barito Selatan (Tesis). Banjarmasin. UNISKA Banjarmasin

Mardinin Amin Namira (20I5). Pengaruh Kompetensi terhadap Kinerja pegawai di Sekretariat Daerah Kabupaten Sindenreng Rappang. Skripsi. Makasar: Universitas Hasanuddin Fakultas Ilmu Sosial Dan Ilmu Politik Negeri Makasar

Pramuji Ramma Indra (2017) Analisis Pengaruh Lingkungan Kerja Terhadap Kinerja Karyawan Pada Dinas Kepemudaan Dan Olahraga Kabupaten Indramayu. Skripsi. Yogyakarta: Universitas Negeri Yogyakarta Fakultas IImu Keolahragaan

Pratiwi. (2009). Panduan Penulisan Skripsi. Yogyakarta: Tugu Publisher

Riyanda Muhammad (2017). Pengaruh Kompetensi dan Disiplin Kerja Terhadap Kinerja Pegawai pada Dinas Perizinan Kota Yogyakarta . Skripsi. Yogyakarta: Fakultas Ekonomi Universitas Negeri Yogyakarta

Sedermayanti dan Syarifudin Hidayat. (20I I). Metodologi Penelitian. Bandung: Mandar Maju

Sugiyono. (2016). Metode Penelitian Kuantitatif, Kualitatif dan R\&D. Bandung: Alfabeta

Wibowo. (2017). Manajemen Kinerja Edisi Kelima. Depok: Rajawali Pers

Winardi.J. (2004). Manajemen Perilaku Organisasi Edisi Revisi. Jakarta: Kencana Prenada Media Group 